Recenzje 



\section{Anna Wylegała}

Instytut Filozofii i Socjologii PAN

orcid.org/0000-0001-5575-4123

awylegala@ifispan.waw.pl

\section{Omer Bartov, Anatomy of a Genocide. The Life and Death of a Town Called Buczacz, New York: Simon \& Schuster, 2018, 416 s.}

Najłatwiej byłoby chyba zacząć tę recenzję od tego, czym książka Omera Bartova o Buczaczu nie jest. Otóż nie jest kolejną mikrohistorią Zagłady; nie jest podróżą sentymentalną; nie jest wreszcie dobrze czytającą się książką amerykańskiego historyka, któremu wydaje się, że zna się na Europie Wschodniej. Istota książki Bartova została mistrzowsko zawarta w tytule i dlatego warto mu się dokładnie przyjrzeć. Anatomy of a Genocide dotyczy ludobójstwa, ale niekoniecznie tylko tego konkretnego ludobójstwa, jakim było wymordowanie buczackich Żydów, gdyż jest to studium mechanizmów ludobójstwa jako takiego. To książka o zagładzie wschodnioeuropejskiego miasteczka, a także o tym, jakie było, zanim przestało istnieć. To wreszcie opowieść o zagładzie Żydów, w mniejszym zakresie zaś również o ludobójstwie na Polakach oraz wysiedleniach i represjach wobec wszystkich grup etnicznych mieszkających w Buczaczu, które położyły kres jego wieloetniczności.

Anatomy of a Genocide składa się z siedmiu rozdziałów, podporządkowanych w dużym stopniu chronologii buczackiej historii w XX w. Rozdział pierwszy („The Gathering Storm” [„Nadciągająca burza”]) jest zgrabnym wprowadzeniem do historii miasta przed 1914 r. - z pewnością bardziej interesującym i potrzebnym dla czytelnika anglojęzycznego, który zawodowo nie zajmuje się Europą Środkowo-Wschodnią. W kolejnym rozdziale („Enemies at Their Pleasure” [„Wrogowie z własnej woli”]) otrzymujemy zapis losów Buczacza podczas pierwszej wojny światowej oraz w okresie polsko-ukraińskich walk o Galicję Wschodnią; oprócz opracowań autor wykorzystuje w nim jako podstawowe źródło dwa niezwykle cenne dokumenty osobiste: spisane w wiele lat po wojnie wspomnienia Oskara Koflera, syna żydowskiego właściciela ziemskiego spod Buczacza, oraz dziennik Antoniego Siewińskiego, ówczesnego polskiego dyrektora gimnazjum. Zarówno dobór źródeł, jak i tematów w tym rozdziale pokazuje, że Bartov nie pisze historii buczackich Żydów w przededniu Zagłady, lecz spogląda z uwagą na historię całej społeczności buczackiej, by kontekst Zagłady zrozumieć. Zadziwiające, jak bardzo opis tego okresu pióra Bartova przypomina to, co działo się w mieście podczas kolejnej wojny, choć w mniejszej skali. Bartov przygląda się eskalacji napięcia między poszczególnymi grupami etnicznymi i skrupulatnie odnotowuje, kto komu ma co za złe. 
Rozdział dotyczący międzywojnia podobnie jak poprzednie został napisany na podstawie bardzo zróżnicowanych źródeł (materiały z archiwów polskich, ukraińskich i niemieckich oraz wspomnienia przedstawicieli wszystkich trzech grup etnicznych zamieszkujących miasto). Jednym z ciekawszych (i zupełnie mi nieznanym) są np. raporty niemieckiego konsula ze Lwowa dr. Gebharda Seelosa, który przyjechał do stolicy Galicji kilka miesięcy przed wybuchem wojny w 1939 r. Sporo miejsca poświęca Bartov przemianom zachodzącym w buczackiej społeczności żydowskiej, rozwojowi ruchu syjonistycznego i komunistycznego, wewnętrznej dynamice tych zmian. Ale tak samo dokładnie pisze o rozwoju nacjonalizmu ukraińskiego czy polityce państwa polskiego wobec swoich mniejszości w skali mikro - to akurat zręcznie pokazując na przykładzie historii buczackiego gimnazjum, które z upływem lat stawało się coraz bardziej polskie. Bartov odnotowuje zachodzący zarówno w społeczności polskiej, jak i ukraińskiej proces splatania się nacjonalizmu z religią i rolę, jaką odegrali w tym księża obu wyznań; zauważa coraz większą izolację, w której żyją poszczególne grupy, zwracając uwagę zwłaszcza na wyjątkowe wyobcowanie Żydów: „Pomiędzy obu rywalizującymi grupami tkwili Żydzi, często postrzegani przez każdą z nich jako wspierający drugą stronę, jako zdradzający sąsiadów lub po prostu dbający tylko o własne interesy" (s. 102) ${ }^{1}$.

Rozdział „Soviet Power” [„Władza sowiecka”] jako pierwszy można by nazwać „koncepcyjnym”; zarówno ten, jak i kolejne rozdziały poza zawartym w nich tematem wyróżnia to, że są zorganizowane wokół nieco odmiennej zasady konstrukcyjnej/narracyjnej. W rozdziale o okupacji sowieckiej polega ona na operowaniu dużymi obrazami i zestawianiu ze sobą obszernych fragmentów źródłowych pochodzących z relacji pojedynczych autorów - Polaków (w tym akurat rozdziale widoczna jest wyraźna przewaga źródeł polskich nad innymi), Żydów i Ukraińców. Widać tu wyraźnie, że Bartov umie czytać dokumenty osobiste krytycznie i dostrzega to, co między wierszami. Zauważa na przykład, że polscy autorzy wypominają swoim dawnym sąsiadom kolaborację z Sowietami, ale zapominają, że sąsiedzi ci nie mieli większych powodów, by czuć przywiązanie do państwa polskiego. Odnotowuje, że polskie narracje o tym okresie składają się z zestawienia dwóch skrajności: absolutnej sielanki sprzed 1939 i apokalipsy po 1939 r. Widzi też analogiczne przekonanie o doznanej krzywdzie wśród Ukraińców i Żydów: „Percepcja losu ofiary i wiktymizacji jest pod wieloma względami typowa dla wszystkich trzech głównych grup: wszystkie bowiem uważały się za główne ofiary różnych konfiguracji okupacji sowieckiej i niemieckiej, każda też prześladowanie pozostałych dwóch grup uznawała za przynajmniej po części usprawiedliwione" (s. 153). Najbardziej uderzające jest

\footnotetext{
${ }^{1} \mathrm{~W}$ cytatach jest przywoływany polski przekład: Anatomia pewnego ludobójstwa. Życie i śmierć Buczacza (tłum. Adam Musiał, Wołowiec, Czarne: 2019). Redakcja dziękuje wydawcy za możliwość wykorzystania tłumaczenia przed jego opublikowaniem. Z tego względu zachowano numery stron oryginału - przyp. red.
} 
to w momencie, gdy autor opisuje przebieg deportacji przeprowadzanych przez Sowietów. Zaczyna od krótkiego przytoczenia liczb i statystyk, z których wynika, że Polacy stanowili 60 procent deportowanych, Żydzi 22 procent (a więc byli nadreprezentowani, gdyż w ogólnej populacji stanowili 10 procent), Ukraińcy 10 procent, Białorusini 8 procent. Następnie przytacza polskie relacje o deportacjach (dość typowe); potem zaś zaznacza, że Ukraińcy postrzegali to zupełnie inaczej i pamiętają, że to oni byli głównymi ofiarami - i przedstawia odpowiednie relacje ukraińskie. Nieco brakuje tu wyraźnego komentarza odautorskiego. Skoro dokumenty osobiste zawierają tak różne wersje wydarzeń, jak z nimi pracować? Jak je weryfikować i analizować? Czy w ogóle używać ich w charakterze czegoś więcej niż ilustracji do tego, co i tak już wiemy? Bartov nie daje na te pytania żadnej odpowiedzi, pozostawiając czytelnika sam na sam z postawionym problemem. Ten zupełny brak refleksji metodologicznej (o którą materiał aż się prosi) jest zaskakujący i nieco rozczarowujący u autora, który udowodnił (chociażby w dotyczącym również Buczacza artykule Wartime Lies and Other Testimonies: Jewish-Christian Relations in Buczacz, 1939-1944, „East European Politics and Societies" 2011), że potrafi się na takową zdobyć.

W rozdziałach dotyczących bezpośrednio Zagłady Bartov konsekwentnie trzyma się zasady ogniskowania tekstu wokół problemu, a nie chronologii. Rozdział „German Order” [„Niemiecki porządek”], moim zdaniem najlepszy, przedstawia zapowiadaną w tytule książki anatomię ludobójstwa - krok po kroku analizuje mechanizmy, które doprowadziły do zagłady buczackich Żydów. Tak naprawdę jest to rozdział o sprawcach, tym cenniejszy, że dominującymi tematami w studiach nad Zagładą są obecnie kwestie doświadczenia różnych grup ofiar, współudziału nieżydowskich sąsiadów oraz pamięci. Bartov nie skupia się na jednej konkretnej grupie sprawców, lecz traktuje ich jako ciało zbiorowe, którego różne elementy (nieraz zaskakujące) składają się na tytułowy „niemiecki porządek". Pisze więc najpierw o wkroczeniu Niemców i o tym, jak przejęli władzę od Ukraińców, którzy na moment zdążyli ją przechwycić. Słusznie unika niepotrzebnych generalizacji i różnicuje swój opis społeczności ukraińskiej, zwracając uwagę na rolę, jaką podczas okupacji niemieckiej odegrali greckokatoliccy księża, w tym bazylianie - w okresie bezkrólewia w czerwcu $1941 \mathrm{r}$. Żydzi, obawiając się pogromu, wysłali do nich delegację z prośbą o wpłynięcie na miejscową ludność (do pogromu nie doszło); następnie bazylianie interweniowali u milicji ukraińskiej w sprawie zdewastowania synagogi. Niemiecka machina ludobójstwa jest w ujęciu Bartova bardzo złożona; składają się na nią z jednej strony elementy dość przewidywalne, takie jak SS i Gestapo z Tarnopola i Czortkowa, żandarmeria z Buczacza, Landkommissar i administracja cywilna oraz ukraińska policja pomocnicza, $\mathrm{z}$ drugiej zaś przypadkowi niemieccy cywile, a także Judenrat i żydowska Ordnungsdienst. Bartov trafnie stwierdza, że „[z]adanie szybkiego zniszczenia ludności żydowskiej wykonali Niemcy poprzez utworzenie lokalnego aparatu składającego się z Ukraińców i Żydów, którzy pomogli im zorganizować masowe morderstwo i je przeprowadzić, oraz 
poprzez rychłą «dekapitację» społeczności, co minimalizowało zorganizowany opór" (s. 179). Opisuje obszernie nie tylko, czym były buczackie Judenrat i Ordnungsdeinst, jakie były motywacje i późniejsze losy ludzi wchodzących w ich skład, lecz także to, jak zmieniały się z czasem relacje żydowskie dotyczące tych instytucji (te późniejsze są znacznie mniej krytyczne). Drugim najciekawszym wątkiem tego rozdziału jest kwestia niemieckich cywili, którzy z różnych względów trafili w czasie wojny do Buczacza, często z całymi rodzinami. Analizując ich powojenne zeznania z procesów karnych zbrodniarzy nazistowskich, Bartov dochodzi do wniosku, że niemożliwością było mieszkać w Buczaczu i nie doświadczyć Zagłady - nie widzieć masowych rozstrzeliwań, ludzi prowadzonych na śmierć, ciał leżących na chodniku. W tym kontekście nieco rozczarowujące jest to, że stosunkowo mało miejsca autor poświęca ukraińskiej policji jako elementowi niemieckiej machiny ludobójczej - szerzej zajmuje się w zasadzie jedynie sprawą szefa buczackiej jednostki Wołodymyra Kaznowskiego (być może nie pozwalała na to skąpość bazy źródłowej, ale z książki się tego nie dowiadujemy).

Rozdział „The Daily Life of Genocide” [„Codzienność ludobójstwa”] jest poświęcony żydowskiemu doświadczeniu Zagłady. Został niemal w całości napisany na podstawie relacji żydowskich - bardzo różnych, w tym wywiadów przeprowadzonych przez autora specjalnie na potrzeby książki. Rozdział ten jest bodaj najtrudniejszy w lekturze, bardzo chaotyczny, ale jednocześnie odznacza się najbardziej wyrazistym stylem. Dopiero w trakcie lektury orientujemy się, że pozornym chaosem rządzi jednak jakaś reguła, a jest nią zorganizowanie narracji wokół doświadczenia pewnych grup ofiar. Zaczynamy od losów osób uratowanych jako noworodki i niemowlęta, następnie przechodzimy do losu dzieci, potem młodych kobiet (pojawia się kwestia przemocy seksualnej, szczególnie ze strony ratujących), młodych mężczyzn i nastolatków (kwestia oporu zbrojnego i partyzantki), na końcu zaś - nielicznych osób starszych. Choć można się pokusić o interpretację, że chaotyczność tego rozdziału oddaje chaotyczność i nieprzewidywalność żydowskiego losu podczas Zagłady, trudno się oprzeć wrażeniu, że lekturę ułatwiłyby śródtytuły. Oczywiście i w tym rozdziale Bartov problematyzuje i wyciąga ogólniejsze wnioski, daleko wykraczające poza opis tego, co działo się w Buczaczu. Stwierdza: „W żydowskich relacjach z okupacji niemieckiej w powiecie buczackim pojawiają się doniesienia zarówno o ratunku ze strony miejscowych chrześcijan, jak i o ich zdradzie" (s. 247) i ocenia, że granica między pomocą a wykorzystaniem była bardzo płynna, a za najbardziej frapujące można by uznać przypadki określane jako niejednoznaczna dobroć (ambivalence of goodness), czyli sytuacje, gdy pomoc nadchodziła z najmniej oczekiwanej strony - Niemiec nie naciskał spustu, ukraiński policjant kazał uciekać. Relacje ocalałych, jak pisze Bartov, są pełen sprzecznych postaw i emocji wobec miejscowych nie-Żydów - bo i oni różnie się zachowywali, często w sposób nieprzewidywalny, motywowani przez kwestie wzajemnie sprzeczne.

Rozdział ostatni, „Neighbors” [„Sąsiedzi”], bardzo mnie zaskoczył. Oczywistością było dla mnie, że za takim tytułem kryć się będzie analiza tego, jaką rolę 
w Zagładzie odegrali polscy i ukraińscy sąsiedzi buczackich Żydów - jako świadkowie, ratujący i sprawcy (niekoniecznie w tej kolejności). Ewentualnie, skoro rozdział o sprawcach został napisany na podstawie zeznań sprawców (oraz w mniejszym stopniu ofiar i świadków), a rozdział o doświadczeniu żydowskim - na podstawie relacji Żydów, że ten rozdział przedstawi Zagładę z p e r s p e kty wy sąsiadów i na podstawie ich głosów. Tymczasem to nie jest ani rozdział o sąsiedzkim współudziale, ani o sąsiedzkiej pomocy, ani nawet o sąsiedzkiej obojętności. Jest to rozdział o tym, co przydarzyło się sąsiadom Żydów w czasie, gdy Żydzi byli mordowani, i wkrótce potem. W porządku chronologicznym dotyczy on: konfliktu polsko-ukraińskiego i rzezi dokonanej na Polakach; wkroczenia Sowietów i wykorzystywania przez nich Polaków w istriebitielnych batalionach; wysiedlenia Polaków przez Sowietów; bilansu zniszczeń po wkroczeniu Sowietów; sowieckich dochodzeń i procesów o kolaborację (w tym mordowanie Żydów); terroru sowieckiego po 1944 r. i wojny z OUN-UPA; deportacji na Syberię; ostatecznego bilansu strat - w $1948 \mathrm{r}$. populacja powiatu zmniejszyła się do 36 tys. (z 140 tys.), a miasta do 4 tys. (w tym 1,5 tys. ukraińskich chłopów przesiedlonych z Polski). Niejako w poprzek chronologii została wpleciona dość powierzchowna analiza kilku późnych relacji ukraińskich o tym, co się działo z Żydami podczas wojny (z mało oryginalnymi tezami o wyparciu i zaprzeczeniu w roli głównej), oraz garść refleksji na temat pomocy udzielonej Żydom przez etnicznych Polaków i powojennych losów tych ostatnich oraz ich relacji z uratowanymi. Wszystko to jest ciekawe, zwłaszcza że rozdział wieńczy nader trafna konkluzja, iż strat, których Buczacz doznał od 1939 r. do końca lat czterdziestych, nie udało się miastu odrobić przez całe powojnie, i że wiele ukraińskich miasteczek podobnych do Buczacza do dziś nie radzi sobie ze statusem miasteczka. Niemniej brakuje mi ogromnie w tym rozdziale jasnego określenia, po co o tym wszystkim czytamy; brakuje klarownej struktury, która nie kazałaby się domyślać, co autor ma na myśli; brakuje, krótko mówiąc, wyraźniejszej obecności autora w narracji, która wielością poruszanych wątków i brakiem spajającego je komentarza po prostu przytłacza.

Nie da się ukryć, że moja surowa ocena ostatniego rozdziału wynika częściowo z zawiedzionych nadziei - chciałam bowiem, by był o czym innym. Brak odrębnego rozdziału o postawach sąsiadów wobec Zagłady to jeden $\mathrm{z}$ dwóch dużych zarzutów, które muszę postawić książce. Wątki ich dotyczące są oczywiście w niej obecne, porozsiewane w wielu miejscach, od rozdziału o sprawcach (ukraińska policja), przez kwestię pomocy i zdrady w rozdziale o żydowskim doświadczeniu, po zakończenie, w którym (trochę nie wiadomo, dlaczego akurat w tym miejscu i dopiero tam) pojawia się druga niewielka analiza treści relacji ukraińskich świadków. Rozpraszając te wątki, Bartov - celowo lub przez niedopatrzenie - rezygnuje z próby całościowego podejścia do tematu, próby bilansu, konceptualizacji. Nie zabiera wyraźnie głosu w trwającej przecież wciąż debacie o Sąsiadach (i Sąsiadach). Być może nie chce, a być może nie czuje się na siłach, gdyż całościowe podejście, zwłaszcza zakładające przytoczenie szacunków licz- 
bowych, jest przedsięwzięciem bardzo trudnym (ale nie niemożliwym, jak pokazuje studium powiatu złoczowskiego autorstwa Anny Zapalec, zamieszczone w tomie Dalej jest noc); jakakolwiek jest tego przyczyna - ogromnie szkoda.

Mój drugi zarzut wiąże się tak naprawdę z pierwszym. Sama konstrukcja książki niejako z definicji zakłada wykorzystywanie różnych źródeł - różnych ze względu na sposób powstania (dokumenty osobiste pisane i ustne, źródła aktowe, ikonografia), a także ze względu na ich autorów. I tu Bartov przez większość książki jest autorem wzorowym, pisząc na podstawie wspomnień polskich, żydowskich oraz ukraińskich (szczególnie trud dotarcia do tych ostatnich jest godny docenienia). Niestety, poprawność ta kończy się w momencie, gdy autor odnosi się bezpośrednio do Zagłady. Ze źródeł polskich i ukraińskich korzysta, gdy pisze o międzywojniu, okupacji sowieckiej i wszystkim, co dzieje się po 1944 r.; Zagłada pozostaje wydarzeniem, o którym opowiadają ofiary i sprawcy. Nieliczne wyjątki to wojenny dziennik Wiktora Petrykewycza oraz głosy kilku polskich świadków z niemieckich procesów, a także pojedyncze wspomnienia pojawiające się doprawdy śladowo, jeśli porównać je z ogromem wykorzystanego materiału relacji żydowskich. Jedyne miejsca, gdzie o Zagładzie mówią przede wszystkim głosy nieżydowskie, to odnotowane już powierzchowne analizy kilku wywiadów z ukraińskimi świadkami, przy czym znaczące jest to, że ukraińskie relacje występują tam nie jako pełnoprawny materiał źródłowy, lecz jako materiał pozwalajacy pokazać mechanizmy rządzące pamięcią biograficzną i wytworzoną przez nie narracją. Mogłoby się wydawać, że Bartov nie sięga do polskich i ukraińskich relacji o Zagładzie, bo się nie zachowały lub nie ma wystarczająco dobrych relacji - ale one są. Bartov jedynie zdawkowo przywołuje dziennik Józefa Anczarskiego, katolickiego księdza, który w okolicach Buczacza spędził całą wojnę i o Zagładzie pisał wielokrotnie; nie sięga w ogóle do wielu szczegółowych relacji z Archiwum Wschodniego Ośrodka Karta, choć cytuje je w innych rozdziałach; nie decyduje się zresztą, z wyjątkiem pojedynczych rozmów, na przeprowadzenie wywiadów z Ukraińcami w Buczaczu, choć rozpoczynając pracę nad książką kilkanaście lat temu, miał jeszcze dostęp do bezcennych wręcz świadków. Krótko mówiąc, opowiadając o Zagładzie, nie korzysta z relacji nieżydowskich albo dlatego że nie potrafi ich znaleźć czy też pozyskać, albo dlatego że tego zrobić nie chce. Nie wiemy tego, niestety, co również niech będzie pewnego rodzaju przyganą - autor ma prawo do swoich decyzji i wyborów, ale czytelnik ma prawo poznać ich uzasadnienie.

Czy te dwa duże zarzuty sprawiają, że cofam początkową ocenę książki Bartova jako dobrej i ważnej? Oczywiście nie. Galicja wciąż jest regionem, w odniesieniu do którego Zagłada nie została zbadana w sposób dostateczny. Bartov stworzył świetną książkę, napisał ją z dużą wrażliwością, poprzedził wieloletnimi solidnymi badaniami, last but not least, napisał ją ciekawie i przystępnie. Z pewnością nie da się już badać Zagłady (a także po prostu historii końca wieloetnicznych społeczności w tym regionie), nie odwołując się do Anatomy of Genocide. Ale z pewnością można (było) to zrobić jeszcze lepiej. 